\title{
Sphingosine 1-phosphate promotes activation of caprine preantral follicle in vitro
}

[Esfingosina 1-fosfato promove ativação de folículos pré-antrais de caprinos in vitro]

\author{
J.E. Nóbrega Jr. ${ }^{1}$, R. Rossetto ${ }^{2}$, M.H.T. Matos ${ }^{2}$, R.N. Chaves $^{2}$, D.M. Magalhães ${ }^{2}$, I.B. Lima-Verde ${ }^{2}$, \\ S.N. Báo ${ }^{3}$, C.C. Campello ${ }^{2}$, J.R. Figueiredo ${ }^{2}$, P.B.D. Gonçalves ${ }^{1}$, J.F.C. Oliveira ${ }^{l^{t}}$ \\ ${ }^{1}$ Universidade Federal de Santa Maria - Santa Maria, RS \\ ${ }^{2}$ Universidade Estadual do Ceará - Fortaleza, CE \\ ${ }^{3}$ Universidade de Brasília - Brasilia, DF \\ ${ }^{\dagger}$ in memoriam
}

\begin{abstract}
This study describes the effect of sphingosine 1-phosphate (S1P) for development of preantral follicle, therefore the activation and follicular viability of caprine follicles cultured in vitro. Ovarian fragments were cultured for 1 or 7 days in Minimum Essential Medium with different S1P concentrations $(0,1,10$, 50,100 or $200 \mathrm{ng} / \mathrm{mL}$ ). All ovarian fragments were processed for histological analysis in optical microscopy, transmission electron microscopy and fluorescence analysis. The treatment using $1 \mathrm{ng} / \mathrm{mL}$ of $\mathrm{S} 1 \mathrm{P}$ was able to maintain the percentage of normal follicles with the progression of the culture from day 1 to 7. At end of the 7-day culture period there was a significant reduction $(\mathrm{P}<0.05)$ in the percentage of primordial follicles in all groups treated with S1P, compared with fresh control (FC) and Control Culture (CC), which was followed by an increase of activated follicles (intermediary, primary and secondary). In addition, the culture for 7 days with media supplemented with $\mathrm{S} 1 \mathrm{P}$ with $1 \mathrm{ng} / \mathrm{mL}$ preserved the ultrastructure of organelles and kept the preantral follicular viability when evaluated by fluorescence microscopy. In conclusion, after 7 days of culture, the $1 \mathrm{ng} / \mathrm{mL}$ of S1P activates the development of preantral caprine follicles, cultured in situ and maintains the oocitary and follicular viability.
\end{abstract}

Keywords: goat, preservation, preantral follicles, sphingosine 1-phosphate, follicular activation

\section{RESUMO}

Este estudo descreve o efeito da esfingosina 1-fosfato $(S 1 P)$ no desenvolvimento de folículos pré-antrais, portanto da ativação e viabilidade de folículos caprinos cultivados in vitro. Fragmentos de ovários foram cultivados por um ou sete dias em meio essencial mínimo com diferentes concentrações de $S 1 P(0,1,10$, 50, 100 ou 200ng/mL). Os fragmentos de ovário foram processados para análise histológica em microscopia óptica, microscopia eletrônica e microscopia de fluorescência. O tratamento usando $1 \mathrm{ng} / \mathrm{mL}$ de SIP foi capaz de manter a porcentagem de folículos normais durante o período de cultivo de sete dias. Ao final do período de cultivo, houve uma redução significativa $(p<0,05)$ na porcentagem de folículos primordiais em todos os grupos tratados com S1P, comparados com os grupos controle (FC e CC), seguida por um aumento do número de folículos ativados (intermediários, primários e secundários). Adicionalmente, na cultura por sete dias com meio suplementado com S1P (1ng/mL), houve preservação da ultraestrutura das organelas e manteve-se a viabilidade dos folículos pré-antrais avaliados por microscopia de fluorescência. Em conclusão, após sete dias de cultura, o meio suplementado com $1 \mathrm{ng} / \mathrm{mL}$ de SIP ativa o desenvolvimento de folículos pré-antrais de caprino, cultivados in situ e mantém as viabilidades oocitária e folicular.

Palavras-chaves: cabra, preservação, folículos pré-antrais, esfingosina 1-fosfato, ativação folicular

Recebido em 4 de fevereiro de 2013

Aceito em 16 de dezembro de 2013

E-mail: j.escariao@gmail.com 


\section{INTRODUCTION}

Follicular activation, i.e. the primordial for primary follicle transition, as well as the subsequent steps of follicular development are critical processes for reproductive biology (Skinner, 2005). However, mechanisms regulating the activation of primordial follicles have not been elucidated so far. Because primordial follicles potentially represent a large source of oocytes in humans and animals, with several possible applications, such as infertility treatment in clinical medicine or improvement of animal reproductive potential, efforts have been focused on developing culture systems for follicles at that stage.

Although sphingolipids were originally thought to play a predominantly structural role as components of the lipid bilayer (Kolesnick, 1987), sphingolipid metabolites - including ceramide, sphingosine, and sphingosine 1phosphate (S1P) - are active mediators that play essential roles in cell growth, survival and death (Hannun, 1996; Merrill et al., 1997). Among these metabolites, S1P which is produced by phosphorylation of sphingosine, has been found to have a wide range of biological actions, including $\mathrm{Ca}^{2+}$ mobilization, reorganization of the cytoskeleton, as well as cell growth, differentiation, survival and motility (Pyne and Pyne, 2000; Spiegel and Milstien, 2000). S1P acts intracellularly as a second messenger and extracellularly as a ligand for $\mathrm{G}$ protein-coupled receptors. In humans, S1P was identified in follicular fluid and related to follicle development (Von Otte et al., 2006).

Some studies have demonstrated that S1P maintain the viability of human embryonic and rat germ cells after in vitro culture (Chae et al., 2004; Hait et al., 2006). An in vivo study demonstrated that S1P given to the ovarian bursa before an exposure to ionizing radiation resulted in a dose-dependent preservation of the ovaries, with complete protection of preantral follicles (Morita et al., 2000). Recently, in vitro studies have shown that S1P decreases follicle apoptosis after irradiation in rats (Kaya et al., 2008), before chemotherapy in mice (Perez et al., 1997; Hancke et al., 2007), as well as in xenografted ovarian tissue in monkeys (Lee et al., 2005).
Although the roles of S1P are known in apoptosis inhibition and in development promotion, studies using $\mathrm{S} 1 \mathrm{P}$ in the culture of caprine preantral follicles were not yet performed. Therefore, the aims of the present study were to 1) investigate the possible influence of different concentrations of S1P on the viability, activation of primordial follicles and further follicular growth after in vitro culture of caprine ovarian tissue, and 2) evaluate the ultra-structure of caprine preantral follicles cultured in vitro in the absence or presence of S1P.

\section{MATERIAL AND METHODS}

Ovarian cortical tissues $(n=10)$ were collected from five adult (1-3 years-old) cyclic, nonpregnant mixed-breed goats at a local abattoir. After recovery, the ovaries were washed in $70 \%$ alcohol, followed by two times in Minimum Essential Medium (MEM) supplemented with $100 \mu \mathrm{g} / \mathrm{mL}$ penicillin and $100 \mu \mathrm{g} / \mathrm{mL}$ streptomycin, being transported to the laboratory within $30 \mathrm{~min}$ in MEM at $4^{\circ} \mathrm{C}$. Unless mentioned otherwise, all chemicals used in the present study were purchased from Sigma Chemical Co. (St Louis, MO, USA).

The ovarian caprine tissues were transferred to 24-well culture dishes containing $1 \mathrm{~mL}$ of culture media. Culture was performed at $39^{\circ} \mathrm{C}$ in $5 \%$ $\mathrm{CO}_{2}$ in a humidified incubator and all the media were incubated for $1 \mathrm{~h}$ prior to use. The basic culture medium (cultured control - without of $\mathrm{S} 1 \mathrm{P})$ consisted of $\alpha$-MEM (pH 7.2 - 7.4) supplemented with ITS (insulin $6.25 \mu \mathrm{g} / \mathrm{mL}$, transferrin $6.25 \mu \mathrm{g} / \mathrm{mL}$ and selenium $6.25 \mathrm{ng} / \mathrm{mL}$ ), pyruvate $0.23 \mathrm{mM}$, glutamine $2 \mathrm{mM}$, hypoxanthine $2 \mathrm{mM}$ and $1.25 \mathrm{mg} / \mathrm{mL}$ of bovine serum albumin (BSA). For the experimental conditions, the medium was supplemented with $\mathrm{S} 1 \mathrm{P}$ at different concentrations $(1,10,50,100$ or $200 \mathrm{ng} / \mathrm{mL}$ ). Each treatment was repeated for quintuplicate and the culture media was replenished every other day.

To evaluate caprine follicular morphology, before culture fresh control (FC) and after one or seven days in culture, all the pieces were fixed in Carnoy's solution for $12 \mathrm{~h}$ and then dehydrated in increasing ethanol concentrations. After paraffin embedding (Vetec, Rio de Janeiro, Brasil), the caprine tissue pieces were cut into 
$7 \mu \mathrm{m}$ sections, and every section was mounted on glass slides and stained with Periodic Acid Schiff - hematoxylin. Follicle stage and survival were assessed microscopically in serial sections. Coded anonymized slides were examined using an optical microscopy under 400X magnification.

The developmental stages of follicles have been defined previously (Silva et al., 2004) as primordial (one layer of flattened granulosa cells around the oocyte) or activated follicles (intermediate: one layer of flattened to cuboidal granulosa cells; primary: one layer of cuboidal granulosa cells, and secondary: two or more layers of cuboidal granulosa cells around the oocyte). These follicles were still classified individually as histologically normal when an intact oocyte was present, surrounded by granulosa cells which are well organized in one or more layers and that have no pyknotic nucleus. Degenerated follicles were defined as those with a retracted oocyte or a pyknotic nucleus, and/or are surrounded by disorganized granulosa cells, which were detached from the basement membrane.

To evaluate follicular activation, the percentages of healthy primordial and activated follicles were calculated before FC and after culture in each medium. Each follicle was examined in every section in which it appeared and matched with the same follicle in adjacent sections to avoid double counting, thus ensuring that each follicle was only counted once, regardless of its size.

For better evaluation of follicular morphology, ultra-structural studies were carried out on fragments from the FC group and those with the best results during the histological analysis after 7 days of culture. Briefly, small pieces $\left(1 \mathrm{~mm}^{3}\right)$ of caprine ovarian tissues were fixed in $2 \%$ paraformaldehyde and $2.5 \%$ glutaraldehyde in $0.1 \mathrm{M}$ sodium cacodylate buffer $(\mathrm{pH} 7.2)$ for $4 \mathrm{~h}$ at room temperature. After fixation, fragments were post-fixed in $1 \%$ osmium tetroxide, $0.8 \%$ potassium ferricyanide, and $5 \mathrm{mM}$ calcium chloride in $0.1 \mathrm{M}$ sodium cacodylate buffer for 1h. The samples were dehydrated through an acetone gradient, and the tissues were embedded in Spurr's resin. Semi-thin sections $(3 \mu \mathrm{m})$ were cut on an ultra-microtome (Reichert Supernova, Heidelberg, German) for light microscopy studies and stained with toluidine blue. The ultra-thin sections $(60-70 \eta \mathrm{m})$ were contrasted with uranyl acetate and lead citrate and examined under a Jeol 1011 (Jeol, Tokyo, Japan) transmission electron microscope. Parameters such as density and integrity of ooplasm and granulose cell organelles, vacuolization, and basement membrane integrity were evaluated.

Based on the results of morphological and histological analysis, the viability or survival of follicles cultured with the concentration of S1P, that provided the outcome height, was further analyzed using a more accurate method of assessment based on fluorescent probes. Caprine preantral follicles from ovarian fragments (FC) and cultured for 7 days with S1P (1ng/mL) were isolated through the mechanical method described by Lucci et al., (1999). Briefly, using a tissue chopper (The Mickle Laboratory Engineering Co., Gomshal, Surrey, UK) adjusted to a sectioning interval of $75 \mu \mathrm{m}$, samples were cut into small pieces, which were placed in MEM and suspended 40 times using a large Pasteur pipette and subsequently 40 times with a smaller Pasteur pipette (diameter of approximately $1600 \mu \mathrm{m}$ ) to dissociate preantral follicles from the stroma. The material obtained was passed through 500- and $100-\mu \mathrm{m}$ nylon mesh filters, resulting in a suspension containing preantral follicles smaller than $100 \mu \mathrm{m}$ in diameter. This procedure was carried out within $10 \mathrm{~min}$ at room temperature.

Thereafter, the viability of preantral follicles was analyzed using a two-color fluorescence cell viability assay based on the simultaneous determination of live and dead cells by calceinAM and ethidium homodimer-1, respectively. While the first probe detected the intracellular esterase activity of viable cells, the second probe labeled nucleic acids of non-viable cells with plasma membrane disruption. The test was performed by adding $4 \mu \mathrm{M}$ calcein-AM and $2 \mu \mathrm{M}$ ethidium homodimer-1 (Molecular Probes, Invitrogen, Karlsruhe, Germany) to the suspension of isolated follicles and incubating at $37^{\circ} \mathrm{C}$ for $10 \mathrm{~min}$. After being labeled, follicles were washed three times in MEM and mounted on a glass microscope slide in $5 \mu \mathrm{l}$ antifading medium (DABCO, Sigma, Deisenhofen, Germany) to prevent photobleaching and finally examined using a DMLB fluorescence microscope (Leica, Germany). The fluorescent signals of 
calcein-AM and ethidium homodimer-1 emitted were collected at 488 and $568 \mathrm{~nm}$, respectively. Oocytes and granulosa cells were considered live if the cytoplasm was stained positively with calcein-AM (green) and the chromatin was not labeled with ethidium homodimer (red).

Percentages of surviving follicles at all stages, primordial and growing, obtained after 1 or 7 days in the various treatments, as well as data from follicle and oocyte diameters, were initially submitted to Kolmogorov-Smirnov and Bartlett's tests to confirm the normal distribution and homogeneity of variance, respectively. Analysis of variance was then carried out using the GLM procedure from the Statistical Analysis System, and Dunnett's test was applied to compare S1P-treated groups against FC and CC. Duncan's test was applied to compare different S1P concentrations and Student's t-test was used to compare means between 1 and 7 days of culture.

\section{RESULTS}

In the present study, a total of 1,950 caprine preantral follicles were analyzed. As expected, the rate of histologically normal preantral follicles was reduced after 1 day or 7 days of culture when compared with FC, regardless of the presence (treatment groups) or absence (CC group) of $\mathrm{S} 1 \mathrm{P}(\mathrm{P}<0.05$; Table 1$)$. In addition, after 1 day, a significantly lower percentage of normal follicles $(\mathrm{P}<0.05)$ was observed in tissues cultured with $100 \mathrm{ng} / \mathrm{mL}$ of S1P (60.2 \%) compared with CC (71.2 \%). Different concentrations of S1P did not affect the percentage of normal follicles evaluated after 1 or 7 days of culture $(\mathrm{P}>0.05)$. However, with the progression of the culture from day 1 to 7 , only the smallest concentration of S1P $1 \mathrm{ng} / \mathrm{mL}$ maintained the percentage of normal follicles $(\mathrm{P}>0.05)$. In all other treatments a significant reduction in the percentage of normal follicles $(\mathrm{P}<0.05$ - Table 1) was observed. Figure 1 shows a representative histological section of normal preantral follicles after seven days of culture in medium supplemented with $\mathrm{S} 1 \mathrm{P}$ at $1 \mathrm{ng} / \mathrm{mL}$.

Table 1. Percentage of preantral follicle survival evaluated by optical microscopy during culture with different concentrations of sphingosine 1-phosphate (S1P) compared with fresh control or cultured control. Values represent the mean \pm SD and each treatment was repeated five times

\begin{tabular}{lccc}
\hline & \multicolumn{3}{c}{ Days of culture } \\
\cline { 2 - 4 } Treatment & $0 *$ & $1 * *$ & $7 * *$ \\
\hline Fresh Control & $86.60 \pm 11.17$ & - & - \\
Cultured Control & - & $71.20 \pm 5.97 \mathrm{a}$ & $55.00 \pm 8.37 \mathrm{~b}$ \\
S1P $1 \mathrm{ng} / \mathrm{mL}$ & - & $66.80 \pm 6.42 \mathrm{a}$ & $57.80 \pm 11.65 \mathrm{a}$ \\
S1P 10ng/mL & - & $67.20 \pm 2.95 \mathrm{a}$ & $52.60 \pm 8.56 \mathrm{~b}$ \\
S1P 50ng/mL & - & $67.00 \pm 8.00 \mathrm{a}$ & $51.20 \pm 2.68 \mathrm{~b}$ \\
S1P 100ng/mL & - & $60.20 \pm 9.55 \mathrm{a}$ & $45.20 \pm 10.28 \mathrm{~b}$ \\
S1P 200ng/mL & - & $61.20 \pm 5.21 \mathrm{a}$ & $48.80 \pm 3.83 \mathrm{~b}$ \\
\hline
\end{tabular}

\footnotetext{
* Fresh control differs significantly from all other treatments $(\mathrm{P}<0.05)$.

** Different concentrations of S1P in the same day of culture did not differ significantly $(\mathrm{P}>0.05)$.

a, ${ }^{b}$ differs between days of culture $(1$ vs. $7 ; \mathrm{P}<0.05)$.
}

The percentage of primordial and activated follicles (intermediary, primary or secondary) in fresh tissue was $39 \%$ and $61 \%$ respectively. After 1 or 7 days of culture there was a significant reduction in the percentage of primordial follicles in all treatments compared with FC $(\mathrm{P}<0.05)$. In addition, after 7 days, a significant reduction in the percentage of primordial follicles compared with $\mathrm{CC}$ was observed in all treatments using S1P. Besides this, after 7 days of culture the percentage of activated follicles in all S1P concentrations were significantly higher compared to $\mathrm{FC}$ or $\mathrm{CC}$ $(\mathrm{P}<0.05-$ Figure 2$)$. Conversely, after 7 days of culture, in all S1P concentrations a significant reduction in the proportion of primary follicles 
compared with FC and CC was observed. Regarding follicular growth, in all treatments, after 1 day of culture, there was no significant effect of S1P on follicular diameter compared with FC, CC or any concentration of S1P. Regarding oocyte growth, no significant change related to oocyte diameter was observed.

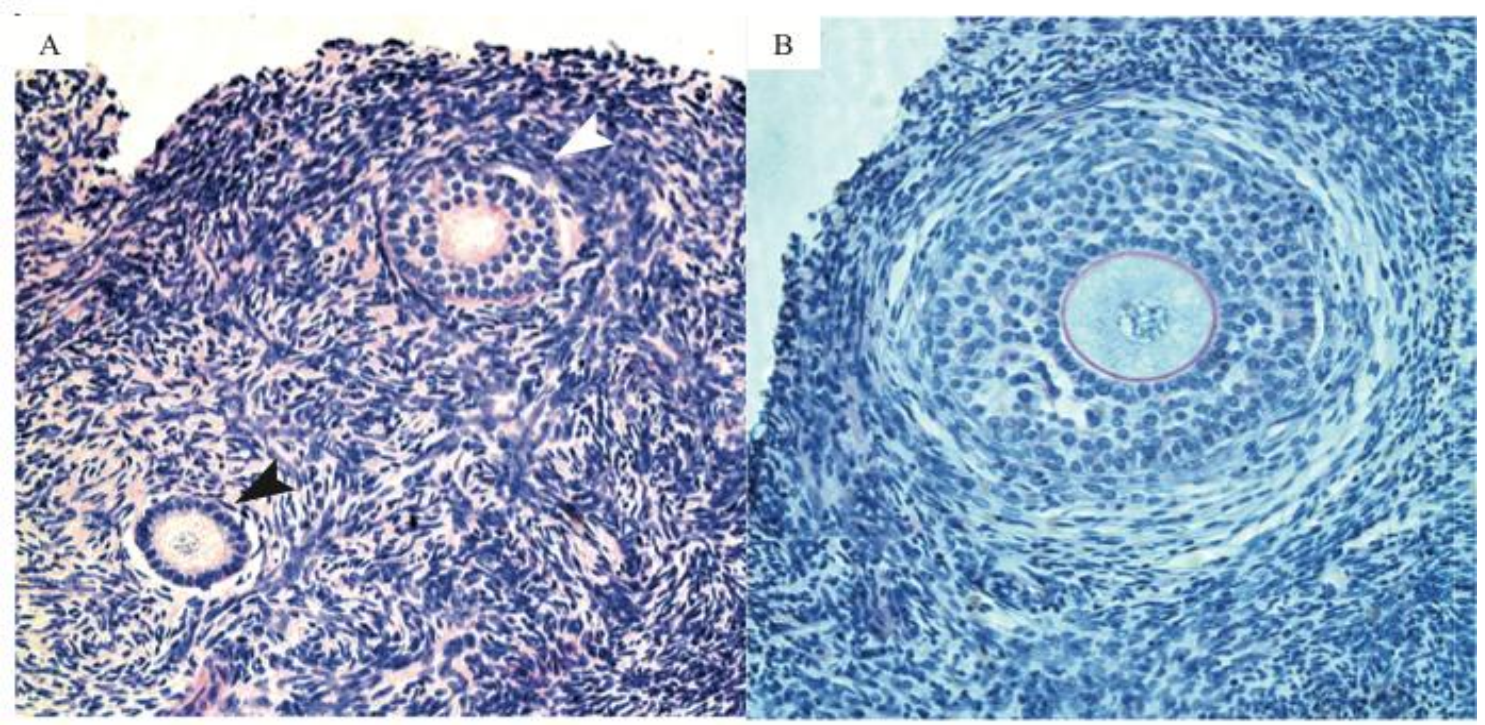

Figure 1. Histological section of tissue cultured for 7 days in $1 \mathrm{ng} / \mathrm{mL}$ of Sphingosine 1-phospahate (S1P), (A) showing normal and activated follicles in different stages of development. Black arrows indicate primary follicles, with one line of cuboidal granulosa cells and white arrows indicate secondary follicles, with two lines of cuboidal granulosa cells (200x). (B) Secondary follicle after 7 days of culture, with multilayers of granulose cells, zone pellucida and theca cells (400x).

To better evaluate follicular quality, ultrastructural analysis was performed using morphologically normal preantral follicles from $\mathrm{FC}$, as well as from treatments that showed the best follicular survival results (tissues cultured in $\mathrm{S} 1 \mathrm{P}$ at $1 \mathrm{ng} / \mathrm{mL}$ ) after 7 days of culture, according to previous histological analysis. Ultra-structural normal follicles from FC had intact basal and nuclear membranes and a large oocyte nucleus. In addition to the sparse vesicles, there were several organelles uniformly distributed in the ooplasm, especially mitochondria. Both the smooth and rough endoplasmic reticulum were present, either as isolated aggregations or as complex associations with mitochondria and vesicles. The oocyte nucleus had uncondensed chromatin. Granulosa cells were ultrastructurally normal and well organized around the oocyte, showing an elongated and large nucleus with an irregular membrane. Welldeveloped rough endoplasmic reticulum and mitochondria with well-developed lamellar cristae were the most evident organelles observed in granulosa cells (Figure 3A). After culture, an increase in cytoplasm vacuolization was observed, although the basal and nuclear membranes remained intact. Furthermore, the lowest S1P concentration $(1 \mathrm{ng} / \mathrm{mL})$ maintained the ultra-structural integrity of granulosa cells (Figure 3B).

When cultured in $50 \mathrm{ng} / \mathrm{mL}$ of S1P for seven days, transmission electron microscope studies revealed some changes in follicular ultrastructure, which are indicative of degeneration. Such follicles presented a substantial irregularity of the follicular, oocyte and nuclear outlines. As degeneration progressed, the ooplasm in these follicles was extremely vacuolated, with the vacuoles often being fused, thus producing a larger vacuolated area, and in some oocytes the nuclear membrane was broken. Cytoplasmic organelles were more randomly observed. In addition, signs of endoplasmic reticulum proliferation and damage to mitochondrial membranes and cristae were observed. The oocyte nucleus appeared retracted and granulosa cells looked swollen (Figure 3C). 


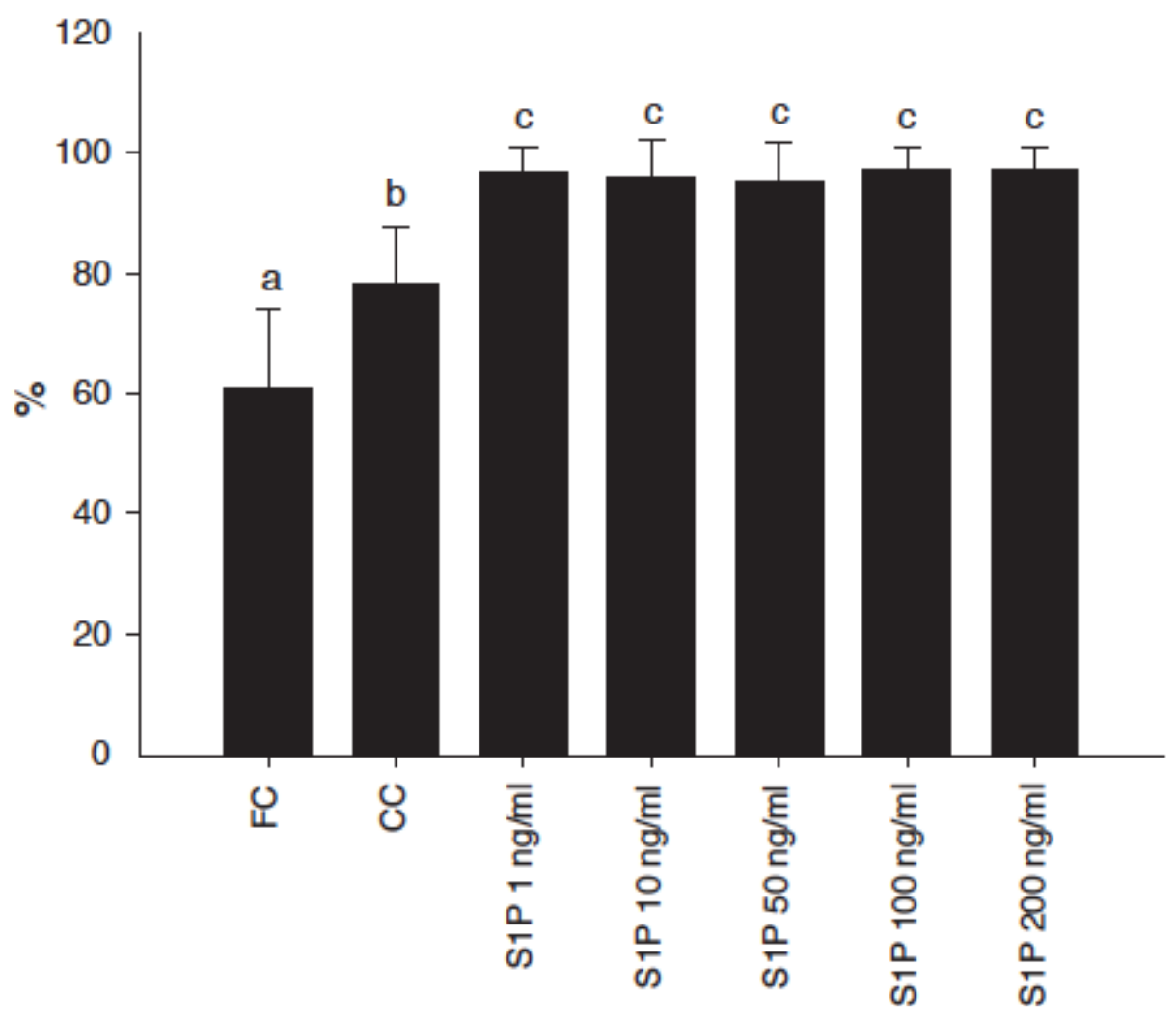

Figure 2. Percentages of primordial and preantral follicles activated after 7 days of culture with different concentrations of sphingosine 1-phosphate (S1P) compared with fresh control (FC) or cultured control (CC). Values represent the mean \pm SD. Significant differences $(\mathrm{P}<0.05)$ are indicated by different letters.
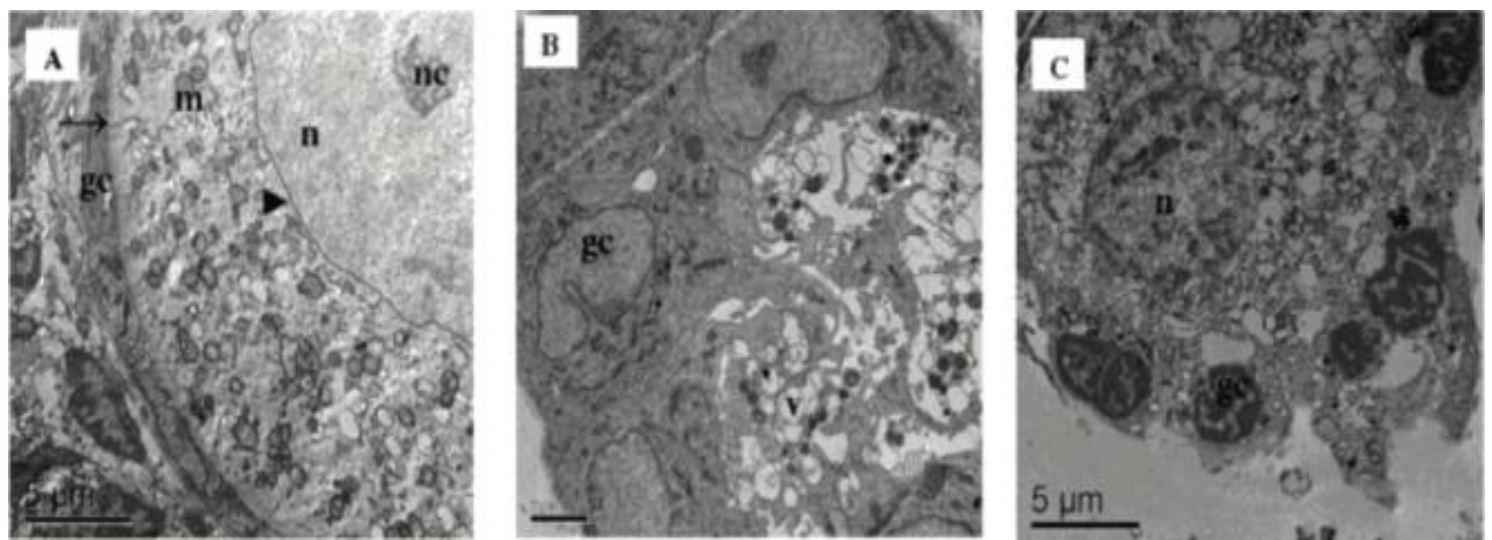

Figure 3. Electron micrographs in caprine ovarian tissue, with preantral follicle. (A) cultured in $1 \mathrm{ng} / \mathrm{mL}$ S1P for 7 days, (B) cultured in $50 \mathrm{ng} / \mathrm{mL}$ of S1P for 7 days and (C) non-cultured follicles. Note the homogeneous cytoplasm with numerous rounded mitochondria (3A). Presence of some vacuoles in the oocyte and the well-preserved granulosa cells (3B). Extreme vacuolization and the large holes present in the cytoplasm, indicative of degeneration, as well as the empty space in degenerated granulosa cells after in vitro culture with $50 \mathrm{ng} / \mathrm{mL}$ of $\mathrm{S} 1 \mathrm{P}$ (3C). gc: granulose cells, m: mitochondria, $\mathrm{n}$ : nucleus, nc: nucleolus, v: vacuole, arrow: oocyte membrane; arrow head: nuclear membrane. 
In the present study, the preantral follicles in ten ovaries were isolated and analyzed previously in FC groups and after seven days of culture with $1 \mathrm{ng} / \mathrm{mL}$ of S1P. This qualitative analysis showed viable follicles with both oocyte and granulosa cells stained in green with calcein-AM before and red non-viable follicle after culture (Figure $4 \mathrm{~A}$ and $\mathrm{B})$.
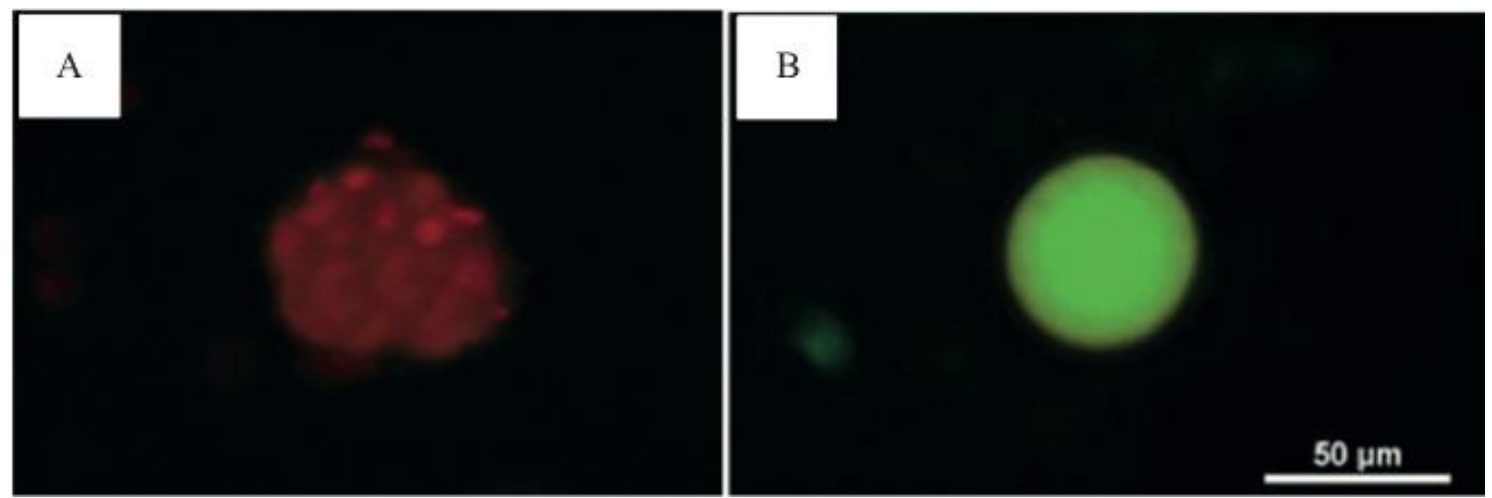

Figure 4. Preantral caprine follicle isolated after 7 days of culture, using fluorescence cell viability with calcein-AM labeled cells (Red fluorescence) non-viable (A) Control Cultured. Viable preantral follicle (green fluorescence) (B) $1 \mathrm{ng} / \mathrm{mL}$ of S1P. Bar $=50 \mu \mathrm{m}$.

\section{DISCUSSION}

The present study described morphological changes in caprine preantral follicles from primary to activated preantral follicle, after culture in medium containing S1P in vitro. The most important finding in this study was the ability of S1P to improve the activation of preantral follicles. As there are only few papers dealing with S1P effects in animals, the concentrations used in this experiment were chosen based on the plasmatic concentrations of $\mathrm{S} 1 \mathrm{P}$ in humans, between $76-300 \mathrm{ng} / \mathrm{mL}$ (Murata et al., 2000).

In the current study, only the smallest concentration of S1P (1ng/mL - Fig 2) maintained the percentage of normal follicles with the progression of the culture from day 1 to 7 . S1P has been found to have several biological actions, including $\mathrm{Ca}^{2+}$ mobilization, reorganization of the cytoskeleton, as well as cell growth, differentiation and survival (Pyne and Pyne, 2000; Spiegel and Milstien, 2000). The mechanisms of S1P in apoptosis are not fully understood. It has been shown that ceramide concentrations in the cell increase on exposure to environmental stresses such as radiation (Verheij et al., 1998), heat shock (Kondo et al., 2000) or oxidative stress (Chan and Goldkorn, 2000). Therefore, whereas stressful stimuli increase the concentrations of ceramide and sphingosine, leading to apoptosis, survival factors activate sphingosine kinase, resulting in accumulation of S1P and consequent suppression of apoptosis (Spiegel and Kolesnick, 2002). This fact may explain our satisfactory results regarding follicular viability after culturing with $1 \mathrm{ng} / \mathrm{mL}$ of S1P. Similar to our results, previous studies have demonstrated that S1P has an anti-apoptotic effect before an exposure to radiation (Morita $e t$ al., 2000; Kaya et al., 2008) or chemotherapy in mice (Perez et al., 1997; Hancke et al., 2007), as well as in monkey xenografted ovarian tissue (Lee et al., 2005), and also protects oocytes from heat shock (Roth and Hansen, 2004). Onions et al. (2008) have demonstrated that S1P can act as a cryoprotectant agent, maintaining follicular viability after cryopreservation of ovarian tissue. Kaya et al. (2008) observed that S1P promoted a small protection in follicular viability when associated with radiation and in rat ovaries.

From day 1 to 7 of culture, the number of primordial follicles was markedly reduced after culturing in 50 and $200 \mathrm{ng} / \mathrm{mL} \mathrm{S1P}$, which was not followed by a concomitant increase in the percentage of primary follicles. These results could be due to primordial follicle atresia and to the maintenance of primary follicle survival. On the other hand, after 7 days of culture, the addition of any S1P concentration to the medium resulted in a reduction in the percentage of primordial follicles with a concomitant increase 
in the percentage stage transition, primary and secondary follicle, compared with FC and CC. The results of this study suggest that S1P treatment stimulates follicular development. In vivo, follicular activation is characterized by changing granulosa cell morphology from flattened to cuboidal, and their further proliferation, which lasts approximately 25-30 days in cow and sheep (Mcnatty et al., 1995; Braw-Tal and Yossefi, 1997). Spiegel and Kolesnick (2002) showed that S1P stimulates mouse preantral follicle growth. After 7 days of culture, caprine follicles showed similar results, however, the molecular mechanisms of S1P action in promoting follicular activation and growth are not clear yet. It is important to note that a great percentage of activated follicles was observed after a small period of culture (seven days) in all medium supplemented with S1P, suggesting that this substance may play an important role in follicular activation and further development.

The present ultra-structural studies revealed differences in the health of follicles cultured in $1 \mathrm{ng} / \mathrm{mL}$ of $\mathrm{S} 1 \mathrm{P}$, when compared to those in medium supplemented with $50 \mathrm{ng} / \mathrm{mL}$ of $\mathrm{S} 1 \mathrm{P}$ for seven days. Using transmission electronic microscopy, although some vacuoles have been observed, important structures such as the basal and nuclear membranes, as well as granulosa cells were preserved even after seven days of culture in the presence of $1 \mathrm{ng} / \mathrm{mL}$ of $\mathrm{S} 1 \mathrm{P}$. Nevertheless, degenerative features were seen in follicles cultured in $50 \mathrm{ng} / \mathrm{mL}$ of $\mathrm{S} 1 \mathrm{P}$, such as extreme ooplasm vacuolization. In addition to ultra-structural analysis, preantral follicles cultured for seven days with $1 \mathrm{ng} / \mathrm{mL}$ of $\mathrm{S} 1 \mathrm{P}$ were further analyzed using a viability assessment, which suggests that this treatment is efficient to maintain preantral follicle viability. The fluorescent probes calcein-AM and ethidium homodimer-1 have been used successfully to assess the viability of bovine and caprine earlystaged follicles (Van Den Hurk et al., 1998; Lopes et al., 2009). This method can be used to analyze viability aspects of follicles, thereby offering a new approach for investigating metabolic and developmental aspects of folliculogenesis in vitro.

\section{CONCLUSION}

In conclusion, after 7 days of culture, the $1 \mathrm{ng} / \mathrm{mL}$ of S1P activates the development of caprine preantral follicles, cultured in situ and maintains the oocitary and follicular viability suggesting that the use of this molecule can be valuable to improve in vitro protocols for development of preantral follicles.

\section{AKNOWLEDGMENTS}

This research was supported by grants from $\mathrm{CNPq}$ - FAPERGS - RENORBIO (grant number 554812/2006-1) and FINEP - Brazil. There are no conflicts of interest. We thank Dr. Maria Fátima Teixeira for the provision of the fluorescence microscope.

\section{REFERENCES}

BRAW-TAL, R.; YOSSEFI, S. Studies in vivo and in vitro on the initiation of follicle growth in the bovine ovary. J. Reprod. Fertil., v.109, p.165-171, 1997.

CHAE, S.S.; PROIA, R.L.; HLA, T. Constitutive expression of the S1P1 receptor in adult tissues. Prostagland. Other Lipid. Mediat., v.73, p.141150, 2004.

CHAN, C.; GOLDKORN, T. Ceramide path in human lung cell death. Am. J. Respir. Cell. Mol. Biol., v.22, p.460-468, 2000.

HAIT, N.C.; OSKERITZIAN, C.A.; PAUGH S.W. et al. Sphingosine kinases, sphingosine 1phosphate, apoptosis and diseases. Biochim. Biophys. Acta., v.1758, p.2016-2026, 2006.

HANCKE, K.; STRAUCH. O.; KISSEL, C. et al. Sphingosine 1-phosphate protects ovaries from chemotherapy-induced damage in vivo. Fertil. Steril., v.87, p.172-177, 2007.

HANNUN, Y.A. Functions of ceramide in coordinating cellular responses to stress. Science., v.274, p.1855-1859, 1996.

KAYA, H.; DESDICIOGLU, R.; SEZIK, M. et al. Does sphingosine-1-phosphate have a protective effect on cyclophosphamide- and irradiation-induced ovarian damage in the rat model? Fertil. Steril., v.89, p.732-735, 2008. 
KOLESNICK, R.N. 1,2-Diacylglycerols but not phorbol esters stimulate sphingomyelin hydrolysis in GH3 pituitary cells. J. Biol. Chem., v.262, p.16759-16762, 1987.

KONDO, T.; MATSUDA. T.; TASHIMA, M. et al. Suppression of heat shock protein-70 by ceramide in heat shock-induced HL-60 cell apoptosis. J. Biol. Chem., v.275, p.8872-8879, 2000.

LEE, D.M.; YEOMAN, R.R.; YU, T. et al. Sphingosine-1-Phosphate Inhibits Apoptosis in Rhesus Monkey Ovarian Tissue In Vitro and May Improve Reproductive Function in Xenografts. Fertil. Steril., v.84, p.S2-S2, 2005.

LOPES, C.A.; SANTOS, R.R.; CELESTINO, J.J. et al. Short-term preservation of canine preantral follicles: Effects of temperature, medium and time. Anim. Reprod. Sci., v.115, p.201-214, 2009.

LUCCI, C.M.; AMORIM, C.A.; BAO S.N. et al. Effect of the interval of serial sections of ovarian tissue in the tissue chopper on the number of isolated caprine preantral follicles. Anim. Reprod. Sci., v.56, p.39-49, 1999.

MCNATTY, K.P.; SMITH, P.; HUDSON, N.L. et al. Development of the sheep ovary during fetal and early neonatal life and the effect of fecundity genes. J. Reprod. Fertil. Suppl., v.49, p.123-135, 1995.

MERRILL, A.H.JR.; SCHMELZ, E.M.; DILLEHAY, D.L. et al. Sphingolipids--the enigmatic lipid class: biochemistry, physiology, and pathophysiology. Toxicol. Appl. Pharmacol., v.142, p.208-225, 1997.

MORITA, Y.; PEREZ, G.I.; PARIS, F. et al. Oocyte apoptosis is suppressed by disruption of the acid sphingomyelinase gene or by sphingosine-1-phosphate therapy. Nat. Med., v.6, p.1109-1114, 2000.

MURATA, N.; SATO, K.; KON, J. et al. Interaction of sphingosine 1-phosphate with plasma components, including lipoproteins, regulates the lipid receptor-mediated actions. Biochem. J., v.352. p.809-815, 2000.
ONIONS, V.J.; MITCHELL, M.R.; CAMPBELL, B.K.; WEBB, R. Ovarian tissue viability following whole ovine ovary cryopreservation: assessing the effects of sphingosine-1-phosphate inclusion. Hum. Reprod., v.23, p.606-618, 2008.

PEREZ, G.I.; KNUDSON, C.M.; LEYKIN, L. et al. Apoptosis-associated signaling pathways are required for chemotherapy-mediated female germ cell destruction. Nat. Med., v.3, p.12281232, 1997.

PYNE, S.; PYNE, N.J. Sphingosine 1-phosphate signalling in mammalian cells. Biochem. J., v.349, p.385-402, 2000.

ROTH, Z.; HANSEN P.J. Sphingosine 1phosphate protects bovine oocytes from heat shock during maturation. Biol. Reprod., v.71, p.2072-2078, 2004.

SILVA, J.R.; VAN DEN HURK, R.; COSTA S.H. et al. Survival and growth of goat primordial follicles after in vitro culture of ovarian cortical slices in media containing coconut water. Anim. Reprod. Sci., v.81, p.273286, 2004.

SKINNER, M.K. Regulation of primordial follicle assembly and development. Hum. Reprod. Update., v.11, p.461-471, 2005.

SPIEGEL, S.; KOLESNICK R. Sphingosine 1phosphate as a therapeutic agent. Leukemia., v.16, p.1596-1602, 2002.

SPIEGEL, S.; MILSTIEN S. Sphingosine-1phosphate: signaling inside and out. FEBS. Lett., v.476, p.55-57, 2000.

VAN DEN HURK, R.; SPEK, E.R.; HAGE, W.J. et al. Ultrastructure and viability of isolated bovine preantral follicles. Hum. Reprod. Update., v.4, p.833-841, 1998.

VERHEIJ, M.; VAN BLITTERSWIJK, W.J.; BARTELINK H. Radiation-induced apoptosis-the ceramide-SAPK signaling pathway and clinical aspects. Acta. Oncol., v.37, p.575-581, 1998.

VON OTTE, S.; PALETTA, J.R.; BECKER, S. et al. Follicular fluid high density lipoproteinassociated sphingosine 1-phosphate is a novel mediator of ovarian angiogenesis. J. Biol. Chem., v.281, p.5398-5405, 2006. 